OPEN ACCESS

Edited by:

Nicolas Oscar Soto-Cruz,

Durango Institute of

Technology, Mexico

Reviewed by:

Guadalupe Virginia Nevárez-Moorillón,

Autonomous University of

Chihuahua, Mexico

Kalidas Shetty,

North Dakota State University,

United States

*Correspondence:

Keshab C. Mondal

mondalkc@gmail.com

Specialty section:

This article was submitted to

Sustainable Food Processing,

a section of the journal

Frontiers in Sustainable Food Systems

Received: 15 March 2021

Accepted: 27 April 2021

Published: 07 June 2021

Citation:

Ghosh K, Adak A, Halder SK and Mondal KC (2021) Physicochemical

Characteristics and Lactic Acid

Bacterial Diversity of an Ethnic Rice

Fermented Mild Alcoholic

Beverage, Haria.

Front. Sustain. Food Syst. 5:680738.

doi: 10.3389/fsufs.2021.680738

\section{Physicochemical Characteristics and Lactic Acid Bacterial Diversity of an Ethnic Rice Fermented Mild Alcoholic Beverage, Haria}

\author{
Kuntal Ghosh ${ }^{1}$, Atanu Adak ${ }^{2}$, Suman K. Halder ${ }^{3}$ and Keshab C. Mondal ${ }^{3 *}$ \\ ${ }^{1}$ Department of Biological Sciences, Midnapore City College, Midnapore, India, ${ }^{2}$ Molecular Biology and Microbial \\ Biotechnology, Life Science Division, Institute of Advance Study in Science and Technology, Guwahati, India, ${ }^{3}$ Department of \\ Microbiology, Vidyasagar University, Midnapore, India
}

Haria, a rice fermented alcoholic beverage, is prepared and consumed by the vast number of Indian tribal people as a staple drink. Lactic acid bacteria are the dominant microbial community in this beverage. Participating lactic acid bacterial diversity in this beverage were determined by using PCR denaturing gradient gel electrophoresis (PCR-DGGE) as Lactobacillus plantarum, Lactobacillus brevis, Lysinibacillus sp., Lysinibacillus fusiformis, and a group of uncultured Bacillus sp. The beverage was enriched with a significant amount of lactic acid $(17.63 \mathrm{mg} / \mathrm{g})$, acetic acid $(0.18 \mathrm{mg} / \mathrm{g})$, folic acid, thiamine, pyridoxine, ascorbic acid, linolenic acid, linoleic acid, palmitic acid, and oleic acid. The phytase activity in this beverage was shown highest $(18.93 \mathrm{U} / \mathrm{g})$ at the fourth day of fermentation. The beverage was also augmented with essential minerals like calcium, ferrous, magnesium, and sodium, whereas the quantity of chromium, lead, cobalt, and nickel were gradually decreased during the course of fermentation. Gas chromatography-mass spectrometry (GC-MS) analysis clearly revealed that three types of esters were produced during fermentation. This study clearly demonstrated that a group of lactic acid bacteria along with other microorganism provide a wide array of bioactive substances make this beverage more nutritious.

Keywords: lactic acid bacteria, DGGE, phytase, lactic acid, esters

\section{INTRODUCTION}

Fermentation is one of the oldest technical skill of human for food preservation and processing. Ethnic fermented foods or beverage are defined as food products from locally available raw materials including grains, legumes, vegetables, milk, fish, and meat prepared by native people following their ancestral knowledge using very simple utensils. Cereal is the most common dietary substance preferred by all human community because of its high productivity (over 60\%) and caloric value (Das et al., 2012). However, its nutritive value and the sensory properties are somehow poor due to presence of natural contaminants, antinutrients, inadequacy of essential amino acids, and fatty acids (Blandino et al., 2003). Microbial (either naturally or starter based) interaction during the course of fermentation transformed the cereal-based food stuffs biochemically and organoleptically into enriched one with adequate micronutrients (vitamins, minerals, amino acids, etc.), health beneficial edible microbes (i.e., probiotics), fermentable sugars (i.e., prebiotic), 
dietary fibers, phytochemicals, digestive enzymes, and exerted many health promoting attributes. Considering these beneficial effects, the grain-based probiotic functional foods are becoming more popular than conventional dairy-based products in Japan and Europe (Nout, 2009).

Rice-based fermented beverages (generally regarded as rice beer) are very popular in the Asia-Pacific region in contrast to alcoholic beer from barley or other grains in Western countries (Steinkraus, 1998). During the rice fermentation, starch matrix supports the growth of specific group of microbes such as lactic acid bacteria (LAB), mold, and yeasts, and these enzymatically almost decomposed the complex substrate into assimilable form, and therefore, fermented beverage is more utilizable and has more health beneficial effects than any solid/semisolid-based fermented counterpart (Ray et al., 2016).

Haria is an inexpensive mild-alcoholic traditional rice fermented beverage, consumed as a staple food by the tribal and low-income groups of lateritic West Bengal, Orissa, Jharkhand, Bihar, Assam, and in many states of Central India (Ghosh et al., 2014, 2020). It has ethnomedicinal importance as a remedial agent for many degenerative and infectious diseases particularly against dysentery, diarrhea, amoebiasis, acidity, and vomiting (Ghosh et al., 2014). During its preparation, parboiled rice is mixed with a traditional starter tablet, popularly called as Bakhar (in Bengali), and kept in heat-sterilized earthen pot for 3-5 days for fermentation (Ghosh et al., 2014). After fermentation, the cream-colored butter-milk-like filtrate is consumed by the people. The starter tablet is unique, which consists of specific part of plants (without any old ferment) that blended with rice dust and shaped in a ball-like structure ( $\sim 10 \mathrm{~g}$ dry weight). The herbal constitute of the starter not only fortifies the rice with different nutraceuticals (phytochemicals) but also provides active microbes that participate in the fermentation. These endophytic microbes are generally safe for human consumption, and their quantitative involvement during the course of fermentation is almost constant, as ethnic people added a specific quantity of starter with the substrate (2-3 g of starter/200 $\mathrm{g}$ of rice).

In our earlier studies, it was observed that the dominant microbes in haria are lactic acid bacteria, bifidobacteria, molds, and yeasts (Ghosh et al., 2014, 2015a,b; Ray et al., 2016). However, the detection of the uncultured bacteria and the nutritional enrichment has not been studied so far. Considering the popularity of this beverage among the tribal groups of West Bengal, a complete portrait of haria should be evaluated. The present research focused on the application of cultureindependent techniques to explore the total community structure of LAB during haria preparation. Simultaneously, reactive metabolites were also examined in relation to the course of fermentation.

\section{MATERIALS AND METHODS}

\section{Sample Collection}

Eighteen (three samples of each day and Bakhar) samples were collected from different villages of West Midnapore and Bankura districts of West Bengal, India. For PCR denaturing gradient gel electrophoresis (PCR-DGGE) analysis, one batch samples was collected randomly and then kept in sterilized container and transported into the laboratory in an ice box and stored in the laboratory at $-20^{\circ} \mathrm{C}$ for further analysis.

\section{Isolation of Total Genomic DNA Pool From Haria}

Haria was initially diluted with sterile distilled water (1:10, $\mathrm{w} / \mathrm{v}$ ), then centrifuged at $1,000 \mathrm{rpm}$ for $10 \mathrm{~min}$ to remove the solid particles, and the supernatant was taken. The supernatant was again centrifuged at 5,000 rpm, and the pellet was washed with $2 \mathrm{ml}$ of buffer ( $\mathrm{pH}$ 8.0) [100 mM Tris$\mathrm{HCl}, 100 \mathrm{mM}$ sodium ethylenediaminetetraacetic acid (EDTA), $100 \mathrm{mM}$ sodium phosphate, $1.5 \mathrm{M} \mathrm{NaCl}$. The pellet was then suspended in $1,000 \mu l$ of buffer ( $\mathrm{pH}$ 8.0) (100mM Tris$\mathrm{HCl}, 100 \mathrm{mM}$ sodium EDTA, $100 \mathrm{mM}$ sodium phosphate, $1.5 \mathrm{M}$ $\mathrm{NaCl})$. Thereafter, $50 \mu \mathrm{l}$ proteinase $\mathrm{K}(10 \mathrm{mg} / \mathrm{mL}$, Sigma $)$ and $25 \mu \mathrm{l}$ lysozyme (40 mg/ml, Sigma), $1 \mathrm{ml}$ of $1 \%$ cetyl trimethylammonium bromide (CTAB) was added and incubated at $37^{\circ} \mathrm{C}$ for $30 \mathrm{~min}$ with inversion of content at 10 -min interval. Then, $50 \mu \mathrm{l}$ of sodium dodecyl sulfate (SDS) (10\%) was added, and the mixture was incubated at $65^{\circ} \mathrm{C}$ for $1 \mathrm{~h}$ with gentle shaking in every 20-min interval following centrifugation at 8,000 rpm. The supernatant was collected, and equal volumes of phenol, chloroform, and isoamyl alcohol (25:24:1, v/v) were added. The aqueous phase was recovered after centrifugation at 10,000 rpm for $10 \mathrm{~min}$, and DNA was precipitated with 0.6 volume of 2isopropanol at $4^{\circ} \mathrm{C}$ for minimum of $30 \mathrm{~min}$. It was centrifuged again at 10,000 rpm for $5 \mathrm{~min}$, and the pellet was washed with $70 \%$ ice-cold ethanol and dissolved in $200 \mu \mathrm{l}$ of TE buffer. The RNA was digested by adding $2 \mu$ l of RNase solution [10 mg of RNase (Sigma) dissolved in $1 \mathrm{ml}$ of Milli-Q water] followed by a 30 -min incubation at $37^{\circ} \mathrm{C}$. The presence of DNA was verified on a $1 \%$ agarose gel.

\section{PCR-DGGE Fingerprinting of LAB}

Extracted DNA was used as a template for PCR amplification. A $\sim 340$ bp of the 16S ribosomal RNA (rRNA) gene was amplified using LAB-specific bacterial primers Lact-F (5'-AGCAGTAGGGAATCTTCCA- $\left.3^{\prime}\right)$ and Lact-R (5'ATTYCACCGCTACACATG-3') (Ritchie et al., 2010). GC clamp was anchored in the $5^{\prime}$ end of the reverse sequence. The PCR reaction mixture of $25 \mu$ l volume was prepared by using $2 \times$ PCR master mix for the required number of reactions. In brief, each reaction mixture contained $12.5 \mu \mathrm{l}$ of PCR master mix, 1 $\mu l$ of each primer (20 pmol), $1 \mu \mathrm{l}$ of DNA template $(50 \mathrm{ng} / \mu \mathrm{l})$, and $9.5 \mu \mathrm{l}$ of sterile Milli-Q water. Samples were amplified in a thermocycler using the following protocol: initial denaturation at $95^{\circ} \mathrm{C}$ for $5 \mathrm{~min} ; 20$ cycles of denaturation at $95^{\circ} \mathrm{C}$ for $30 \mathrm{~s}$, annealing at $55^{\circ} \mathrm{C}$ for $1 \mathrm{~min}$ with an increase in temperature of $0.5^{\circ} \mathrm{C}$ in each cycle, extension at $72^{\circ} \mathrm{C}$ for $1 \mathrm{~min} ; 10$ cycles of denaturation at $95^{\circ} \mathrm{C}$ for $30 \mathrm{~s}$, annealing at $60^{\circ} \mathrm{C}$ for $1 \mathrm{~min}$, extension at $72^{\circ} \mathrm{C}$ for $1 \mathrm{~min}$; and final extension at $72^{\circ} \mathrm{C}$ for $7 \mathrm{~min}$.

DGGE was performed with a DCode electrophoresis system (Bio-Rad) with gel dimension of $16 \mathrm{~cm} \times 16 \mathrm{~cm} \times 1 \mathrm{~mm}$. PCR products were loaded onto a $38-53 \%$ gradient of urea and formamide in a polyacrylamide gel (8\%) and electrophoresed at a 
constant temperature of $60^{\circ} \mathrm{C}$ and a constant voltage of $60 \mathrm{~V}$ for $16 \mathrm{~h}$. Gels were stained with ethidium bromide $(0.5 \mathrm{mg} / \mathrm{L})$ in TAE buffer for $20 \mathrm{~min}$, destained in sterile deionized water for $10 \mathrm{~min}$, and viewed by UV transillumination.

The visualized DGGE bands were excised from the original gel and incubated in $100 \mu \mathrm{l}$ sterile distilled water at $4{ }^{\circ} \mathrm{C}$ overnight. A $1-\mu 1$ aliquot of elution was subjected to the PCR amplification using corresponding primers, without GC clamp. PCR products were excised from 1\% agarose gel and purified with a HiPurA Quick Gel Purification Kit (HiMedia, India) and then subjected to sequencing. Forward and reverse DNA sequencing reaction of PCR amplicons were carried out with respective primers using BDT v3.1 cycle sequencing kit on ABI 3730xl Genetic Analyzer.

\section{Texture Analysis}

The tests were performed by a texture analyzer (TA-XT Plus, UK). A back extrusion test can provide the means to contain a volume of semisolid material to enable its testing. The vessel containing the sample was centrally located beneath a disk plunger, which then moved down into the sample and extrudes it up and around the edge of the disk. The diameter of the disk was $35 \mathrm{~mm}$, and $75 \%$ of the sample holder was filled with test sample. When a 5-g surface triggered was attained (i.e., the point at which the disks lower surface was in full contact with the product), the disk proceeds to penetrate to a depth of $25 \mathrm{~mm}$. At this point, the probe was allowed to return to its original position. The force area of the curve up to this point was taken as a measurement of consistency, and force at this point was the indication of firmness. The maximum negative force was recorded to indicate the cohesiveness.

\section{Viscosity}

Solid free liquid was extracted by centrifugation of fermented materials at 5,000 rpm for $5 \mathrm{~min}$. The apparent viscosity was measured on a Bohlin CVO rheometer (Malvern Instrument, Malvern, UK) with a cone and plate geometry (CP $2 \% / 20 \mathrm{~mm}$ diameter) maintaining a gap of $70 \mu \mathrm{m}$. Viscosity measurements were carried out on beverages previously adapted at $25^{\circ} \mathrm{C}$ for $1 \mathrm{~h}$.

\section{Analysis of Organic Acids Content}

Water/salt-soluble extract from haria was prepared following the method of Ghosh et al. (2015a). Briefly, $10 \mathrm{~g}$ of haria was diluted with $30 \mathrm{ml}$ of $50 \mathrm{mM}$ Tris- $\mathrm{HCl}(\mathrm{pH} \mathrm{8.8),} \mathrm{kept} \mathrm{at}$ $4^{\circ} \mathrm{C}$ for $1 \mathrm{~h}$, vortexing at 15 -min intervals, and centrifuged at $20,000 \times \mathrm{g}$ for $20 \mathrm{~min}$. The supernatant, containing the water/saltsoluble fraction, was filtered through a Millex-HA $0.22-\mathrm{mm}$ pore size filter (Millipore Co., Bedford, MA) and used for analyses. The extracts were analyzed by high-performance liquid chromatography (HPLC) using an Agilent HPLC system (Agilent Technology, 1200 infinity series). Organic acids were determined by using Zorbax SB C18 column, and elution was carried out at $60^{\circ} \mathrm{C}$, with a flowrate of $0.6 \mathrm{ml} / \mathrm{min}$, using $10 \mathrm{mM} \mathrm{H}_{2} \mathrm{SO}_{4}$ as mobile phase (Coda et al., 2011).

\section{Determination of Hydrosoluble Vitamins}

Hydrosoluble vitamins were analyzed by reverse-phase highperformance liquid chromatography (RP-HPLC) as mentioned by Ghosh et al. (2015b).

\section{Fatty Acid Analysis}

Approximately, $20 \mathrm{mg}$ of oven-dried samples (added $100 \mu \mathrm{g}$ heptadecanoic acid as internal standard) was suspended in $1 \mathrm{ml}$ of $5 \%$ methanolic solution of potassium hydroxide and saponified at $70^{\circ} \mathrm{C}$ for $1 \mathrm{~h}$. Then, the $\mathrm{pH}$ of the mixture was adjusted to 2 with $\mathrm{HCl}$. A mixture of $1 \mathrm{ml}$ water and $1 \mathrm{ml}$ chloroform was added, and the samples were shaken vigorously. The chloroform phase was collected after the centrifugation (4,000 rpm, $\left.4^{\circ} \mathrm{C}, 15 \mathrm{~min}\right)$, and the extraction was repeated again from the upper phase with $1 \mathrm{ml}$ chloroform. The collected chloroform phases were pooled and evaporated under stream of nitrogen. One milliliter of $14 \%$ methanolic solution of borontrifluoride was added to the saponified samples and incubated at $70^{\circ} \mathrm{C}$ for $1.5 \mathrm{~h}$. The fatty acid methyl-esters (FAMEs) were partitioned with hexane, which was evaporated to dryness under nitrogen. Finally, the derivatized samples were reconstituted in $100 \mu l$ hexane before chromatographic analysis.

The extracted samples were analyzed by gas chromatography (Agilent Technology, 6890N GC), equipped with a flame ionization detector (FID). A capillary column, HP-Innowax $(60 \mathrm{~m} \times 0.25 \mathrm{~mm} \times 0.5 \mu \mathrm{m})$ was used. The temperature of the injector and detector was both set to $250^{\circ} \mathrm{C}$. The oven temperature was held at $50^{\circ} \mathrm{C}$, for $2 \mathrm{~min}$, then programmed to rise from 50 to $200^{\circ} \mathrm{C}$, at $20^{\circ} \mathrm{C} / \mathrm{min}$, and from 200 to $240^{\circ} \mathrm{C}$ at $3^{\circ} \mathrm{C} / \mathrm{min}$, and finally held at $50 \mathrm{~min}$ at $240^{\circ} \mathrm{C}$. Nitrogen was used as carrier gas.

\section{GC-MS Analysis}

The ripened fermented material (fourth day) was extracted with dichloromethane and then analyzed by following the method of Ghosh et al. (2015a) in a gas chromatography-mass spectrometry (GC-MS) using a PerkinElmer Clarus 600C mass spectrometer equipped with a split/splitless injector and a flame ionization detector (FID). The compounds were identified by Perkin-Elmer inbuilt NIST mass spectral library.

\section{Analysis of Organic Acids Content}

Water/salt-soluble extract from haria was prepared following the method of Ghosh et al. (2015a). Briefly, $10 \mathrm{~g}$ of haria was diluted with $30 \mathrm{ml}$ of $50 \mathrm{mM}$ Tris- $\mathrm{HCl}(\mathrm{pH} \mathrm{8.8),} \mathrm{kept} \mathrm{at}$ $4^{\circ} \mathrm{C}$ for $1 \mathrm{~h}$, vortexing at 15 -min intervals, and centrifuged at $20,000 \times \mathrm{g}$ for $20 \mathrm{~min}$. The supernatant, containing the water/saltsoluble fraction, was filtered through a Millex-HA $0.22-\mathrm{mm}$ pore size filter (Millipore Co., Bedford, MA) and used for analyses. The extracts were analyzed by high-performance liquid chromatography (HPLC) using an Agilent HPLC system (Agilent Technology, 1200 infinity series). Organic acids were determined by using Zorbax SB C18 column, and elution was carried out at $60^{\circ} \mathrm{C}$, with a flowrate of $0.6 \mathrm{ml} / \mathrm{min}$, using $10 \mathrm{mM} \mathrm{H}_{2} \mathrm{SO}_{4}$ as mobile phase (Ghosh et al., 2015b). 


\section{Phytase Activity}

Phytase activity in the ferment was measured according to the method of Shimizu (1992) with slight modification. The reaction mixture, containing $150 \mu \mathrm{l}$ of extract and $600 \mu \mathrm{l}$ of substrate ( $3 \mathrm{mM} \mathrm{Na}$-phytate in $0.2 \mathrm{M} \mathrm{Na}$-acetate, $\mathrm{pH} 4.0$ ), was incubated at $45^{\circ} \mathrm{C}$. The reaction was stopped by adding $750 \mu \mathrm{l}$ of $5 \%$ trichloroacetic acid. The released inorganic phosphate was measured spectrophotometrically at $700 \mathrm{~nm}$ by adding $750 \mu \mathrm{l}$ of freshly prepared color reagent. The coloring reagent composed of four volumes of $1.5 \%(\mathrm{w} / \mathrm{v})$ ammonium molybdate in $5.5 \%$ $(\mathrm{v} / \mathrm{v})$ sulfuric acid solution and one volume of $2.7 \%(\mathrm{w} / \mathrm{v})$ ferrous sulfate solution. One unit (U) of phytase activity was defined as the amount of enzyme required to liberate $1 \mathrm{nmol}$ of phosphate per minute under the assay condition.

\section{Determination of Free Minerals}

The contents of free minerals including heavy metals in fermented and unfermented rice were determined by using an atomic absorption spectrophotometer (AAS) [Shimadzu Analytical (India) Pvt. Ltd] following the method described by Ghosh et al. (2015b). Briefly, rice products (5 g) were dissolved in $25 \mathrm{ml}$ of deionized water and homogenized. Then, it was centrifuged at $12,000 \mathrm{rpm}$ for $10 \mathrm{~min}$, and the supernatant was used for analysis.

\section{Statistical Analysis}

All the laboratory experiments were carried out for five times, and the values were represented as the mean \pm standard deviation (SD). Data were statistically analyzed using one-way ANOVA and the Duncan's multiple range test in Sigma Plot 11.0 (USA) to determine the significant relationship between the means.

\section{RESULTS}

\section{PCR-DGGE Fingerprinting of Lab}

PCR-DGGE fingerprinting of LAB in haria is shown in Figure 1. Using the NCBI homology search, the sequenced DGGE bands were analyzed to identify the corresponding LAB with higher than $97 \%$ nucleotide sequence identities (Table 1). Four different genus were observed in haria: Lactobacillus sp. (bands a, c, h), Lactiplantibacillus sp. (band b), Lysinibacillus sp. (bands df), and the uncultured Bacillus sp. (g, i). The starter tablet,
Bakhar, contained six types of bacteria (a-f). The "g" and "i" bands reflected the uncultured Bacillus sp., and the "a" and "c" were Lactobacillus brevis. The "d," "e," and "f" bands were Lysinibacillus fusiformis, Lysinibacillus sp., and uncultured Lysinibacillus sp., respectively. It is intriguing to note that the Lysinibacillus sp. was not survived in rice during fermentation as evidenced by the disappearance of " $e$ " band after the first day. On the other hand, Lactiplantibacillus argentoratensis, uncultured Lactobacillus sp., and uncultured Bacillus sp. were gradually mounted during the course of fermentation as evidenced by the dominancy of "b," "g," and "i" (Figure 1).

\section{Texture Analysis}

Textural properties of the residual rice granules before and after fermentation were measured by a texture analyzer (TA-XT

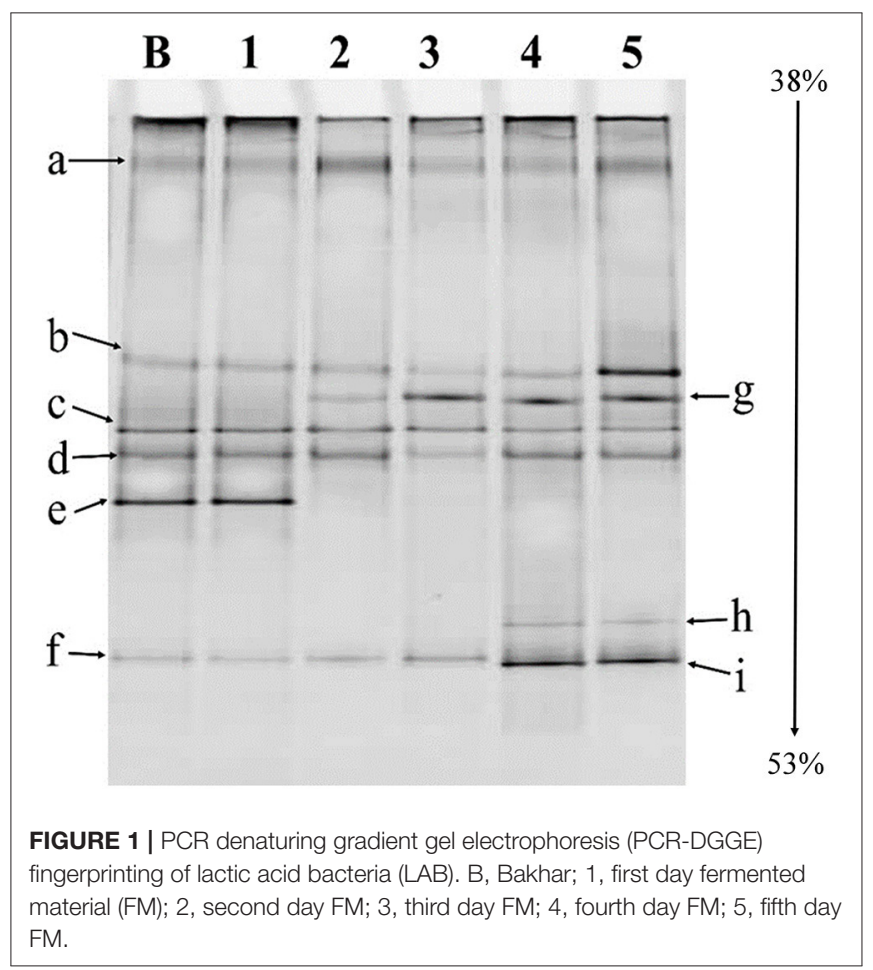

TABLE 1 | Species-identification of the fragments excised from PCR-DGGE shown in Figure 1.

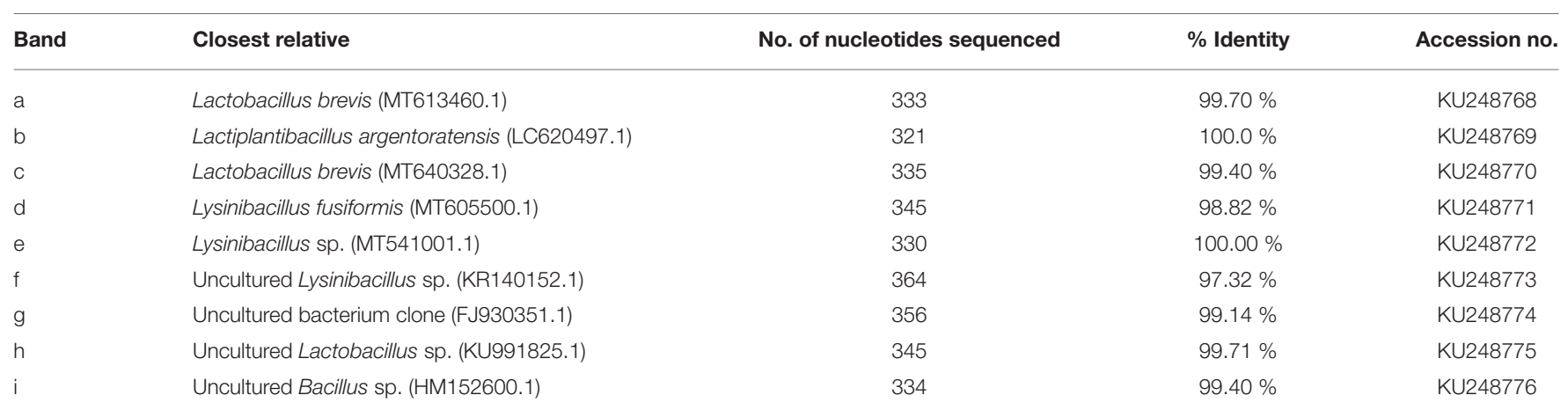




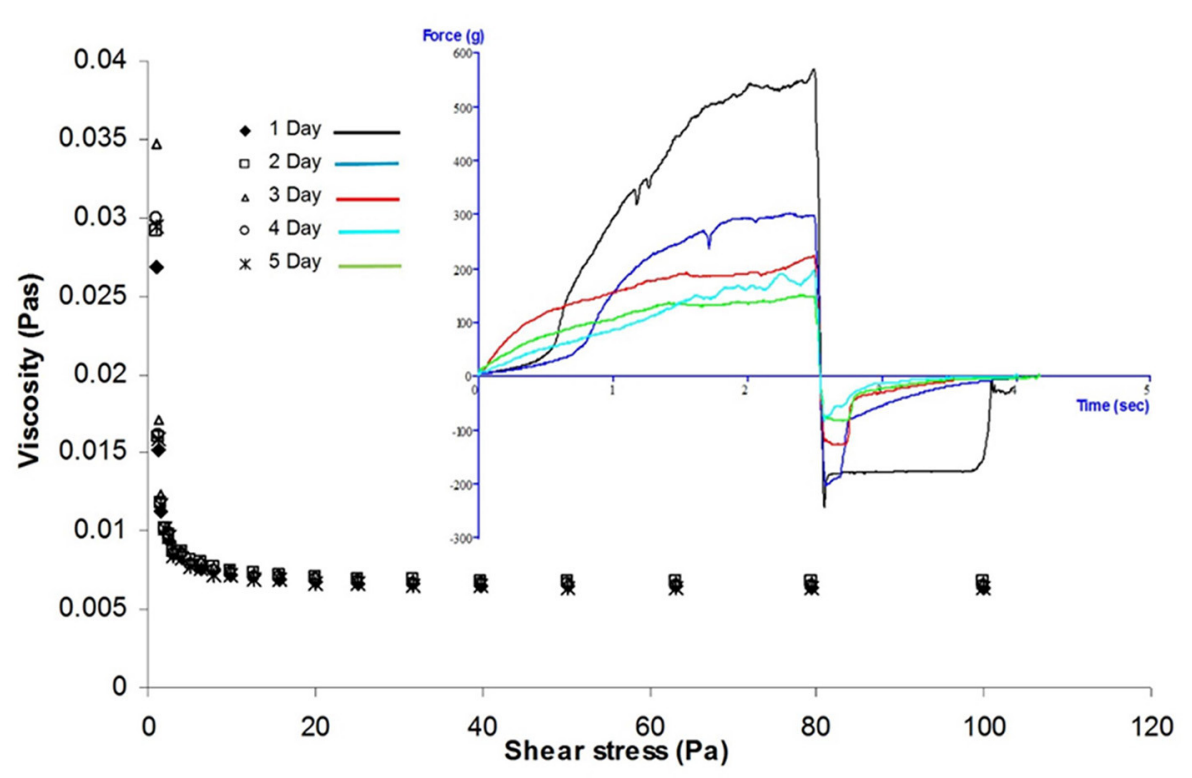

FIGURE 2 | Changes of texture and apparent viscosity during haria preparation.

TABLE 2 | Lactic acid, acetic acid, and hydrosoluble vitamins content of haria.

\begin{tabular}{|c|c|c|c|c|c|c|c|}
\hline \multirow[t]{2}{*}{ Fermentation time (day) } & \multicolumn{2}{|c|}{ Organic acid content (mg/g) } & \multicolumn{5}{|c|}{ Vitamin content $/ 100 \mathrm{~g}$} \\
\hline & Lactic acid & Acetic acid & Folic acid $(\mu \mathrm{g})$ & Thiamine (mg) & Riboflavin $(\mu \mathrm{g})$ & Pyridoxine $(\mu \mathrm{g})$ & Ascorbic acid $(\mu \mathrm{g})$ \\
\hline 0 & $1.11 \pm 0.12^{f}$ & $0.02 \pm 0.01^{\mathrm{e}}$ & $32.14 \pm 1.21^{e}$ & $0.43 \pm 0.04^{e}$ & $72.03 \pm 0.81^{a}$ & $3.23 \pm 0.09^{f}$ & $\mathrm{O}^{f}$ \\
\hline 1 & $4.63 \pm 0.58^{\mathrm{e}}$ & $0.06 \pm 0.01^{d}$ & $180.83 \pm 3.03^{c}$ & $0.68 \pm 0.18^{e}$ & $39.18 \pm 0.39^{b}$ & $93.65 \pm 0.92^{\mathrm{e}}$ & $93.46 \pm 1.26^{\mathrm{e}}$ \\
\hline 2 & $8.11 \pm 0.61^{d}$ & $0.09 \pm 0.02^{\mathrm{cd}}$ & $268.33 \pm 5.28^{a}$ & $1.09 \pm 0.26^{d}$ & $28.81 \pm 0.24^{c}$ & $211.32 \pm 2.36^{d}$ & $252.31 \pm 3.33^{d}$ \\
\hline 3 & $11.55 \pm 0.80^{c}$ & $0.11 \pm 0.03^{b c}$ & $201.28 \pm 4.91^{b}$ & $2.35 \pm 0.33^{c}$ & $20.31 \pm 0.21^{d}$ & $346.35 \pm 4.08^{c}$ & $428.62 \pm 4.39^{c}$ \\
\hline 4 & $13.12 \pm 0.83^{b}$ & $0.13 \pm 0.03^{\mathrm{b}}$ & $179.43 \pm 4.48^{c}$ & $2.93 \pm 0.33^{b}$ & $18.44 \pm 0.21^{e}$ & $432.81 \pm 4.69^{b}$ & $512.45 \pm 6.02^{b}$ \\
\hline 5 & $17.63 \pm 0.83^{a}$ & $0.18 \pm 0.04^{a}$ & $155.83 \pm 4.01^{d}$ & $3.41 \pm 0.38^{a}$ & $16.31 \pm 0.19^{f}$ & $481.62 \pm 5.02^{\mathrm{a}}$ & $538.24 \pm 6.51^{a}$ \\
\hline
\end{tabular}

Values are the mean $( \pm S D)$ of lactic acid $(F=392.581 ; d f=5,24 ; P<0.001)$, acetic acid $(F=23.225 ; d f=5,24 ; P<0.001)$, folic acid $(F=1825.768 ; d f=5,24 ; P<0.001)$, thiamine $(F=100.977 ; d f=5,24 ; P<0.001)$, riboflavin $(F=13,509.267 ; d f=5,24 ; P<0.001)$, pyridoxine $(F=15,574.409 ; d f=5,24 ; P<0.001)$, ascorbic acid $(F=13,743.334$; $d f=5,24 ; P<0.001)$. Values within a column followed by different superscripts are significantly different according to ANOVA (Duncan's multiple range tests).

Plus, UK). From the force vs. time graph, firmness, consistency, and cohesiveness were calculated. Firmness, consistency, and cohesiveness were measured from maximum positive force, mean positive area, and maximum negative force of the curve, respectively. The firmness of haria was gradually decreased from $570.1 \mathrm{~g}$ force (first day) to $147.9 \mathrm{~g}$ force (fifth day) (Figure 2). Consistency and cohesiveness were also gradually decreased during fermentation, and their value was 272.745 and $84.5 \mathrm{~g}$ force, respectively, at the end of the fermentation.

\section{Viscosity}

Viscosity of the fermented soup after separation of the rice granule was measured on a Bohlin CVO rheometer. From the graph, it was observed that viscosity of the fermented liquid was gradually increased up to third day $(0.0347 \mathrm{~Pa}$ s) and then decreased (0.0294 Pa s at fifth day) (Figure 2). The decrease in the apparent viscosity of the haria with the increase in shear rate at $25^{\circ} \mathrm{C}$ temperatures evaluated that the fluid has shear thinning characteristics. Hence, this is non-Newtonian shear thinning fluid.

\section{Organic Acid Content}

The organic acids content of the fermented material was quantified by HPLC, and it was observed that the concentration of lactic acid (17.63 mg/g) and acetic acid $(0.18 \mathrm{mg} / \mathrm{g})$ was accumulated in highest level on the fifth day of fermentation (Table 2).

\section{Vitamin Content}

Haria contains different types of hydrosoluble vitamins. Folic acid, thiamine, pyridoxine, and ascorbic acid contents were relatively higher in the ripened material than the unfermented one. Folic acid content was highest on the second day $(268.33 \mu \mathrm{g} / 100 \mathrm{~g})$ and then declined. Besides, thiamine (3.41 $\mathrm{mg} / 100 \mathrm{~g})$, pyridoxine $(481.62 \mu \mathrm{g} / 100 \mathrm{~g})$, and ascorbic acid $(538.24 \mu \mathrm{g} / 100 \mathrm{~g})$ content gradually increased during the course 
of fermentation (Table 2). On the other hand, riboflavin content gradually decreased during fermentation.

\section{Fatty Acid Analysis}

Dietary fatty acids play a significant role in the daily caloric intake of the human population in India. Health professionals worldwide recommend a reduction in the overall consumption of trans-fatty acids (TAs) and cholesterol while emphasizing the need to increase intake of n-3 polyunsaturated fats (Daley et al., 2010). The fatty acids profile of haria has been tabulated in Table 3. It was found that palmitic acid (C16:0) was the most abundant saturated fatty acid present in haria. The amount was gradually increased up to the third day $(18.84 \mu \mathrm{g} / \mathrm{mg})$ and then declined. Oleic acid (C18:1) content reached the highest level of $14.11 \mu \mathrm{g} / \mathrm{mg}$ on the second day. Haria also contained two essential fatty acids: linolenic acid $(13.51 \mu \mathrm{g} / \mathrm{mg})$ and linoleic acid (0.39 $\mu \mathrm{g} / \mathrm{mg})$.

\section{Phytase Activity and Determination of Minerals}

Phytase activity in haria reached the highest level at fourth day $(18.93 \mathrm{U} / \mathrm{g})$ and then declined (Figure 3). Simultaneously, it was observed that the quantities of $\mathrm{Ca}^{++}(0.77 \mathrm{ppm}$ on second day), $\mathrm{Fe}^{++}$(0.43 ppm on fifth day), $\mathrm{Mg}^{++}$(5.42 ppm on third day), $\mathrm{Mn}^{++}$(0.81 ppm on first day), and $\mathrm{Na}^{+}(0.99 \mathrm{ppm}$ on third day) were profoundly higher than the unfermented rice (Table 3 ). On the other hand, $\mathrm{Cu}^{++}$and $\mathrm{Cr}^{+++}$contents gradually declined during the fermentation, and their quantities were 0.21 and 0.04 ppm, respectively, in the consumable product (Table 3). $\mathrm{Pb}^{++}$, $\mathrm{Co}^{++}$, and $\mathrm{Ni}^{++}$were not detected in the mature product.

\section{GC-MS Analysis}

The type and occurrence of volatile compounds were analyzed in GC-MS, which was equipped with PerkinElmer inbuilt NIST mass spectral library. Eleven types of volatile compounds were detected in haria by GC-MS (Table 4). These are dichloroacetic acid heptadecyl ester; bicyclo (3.3.1) non-2-ene; ethanone,1-(2,4,6-trihydrophenyl); chloroacetic acid, dodecyl ester; 2h-indene3,3a,4,5,6,7hexahydro; mucoinisitol, hexaacetate; chloroacetic acid, tetradecyl ester; 1-acetyl-3-(6-methyl-3-pyridyl) pyrazoline; epi-inositol, hexaacetate; N-(3-methyl-4-propionylphenyl) acetamide; and 1h-indene,2,3,4,5,6,7-hexahydro.

\section{DISCUSSION}

PCR-DGGE technique for the first time applied by ben Omar and Ampe (2000) to study the community structure of LAB in Mexican fermented maize dough Pozol. In this study, a LAB-specific primer was used to amplify the specific gene of LAB community only in haria, and thereafter, DGGE fingerprint has been constructed (Figure 1). It was observed that $L$. brevis, $L$. argentoratensis, and $L$. fusiformis present throughout the fermentation in haria. Lysinibacillus sp. is an uncommon group originated from starter, and this may be associated with the rice dust. Other participating microbes in ferment are endophytic in origin and derived from the starter.

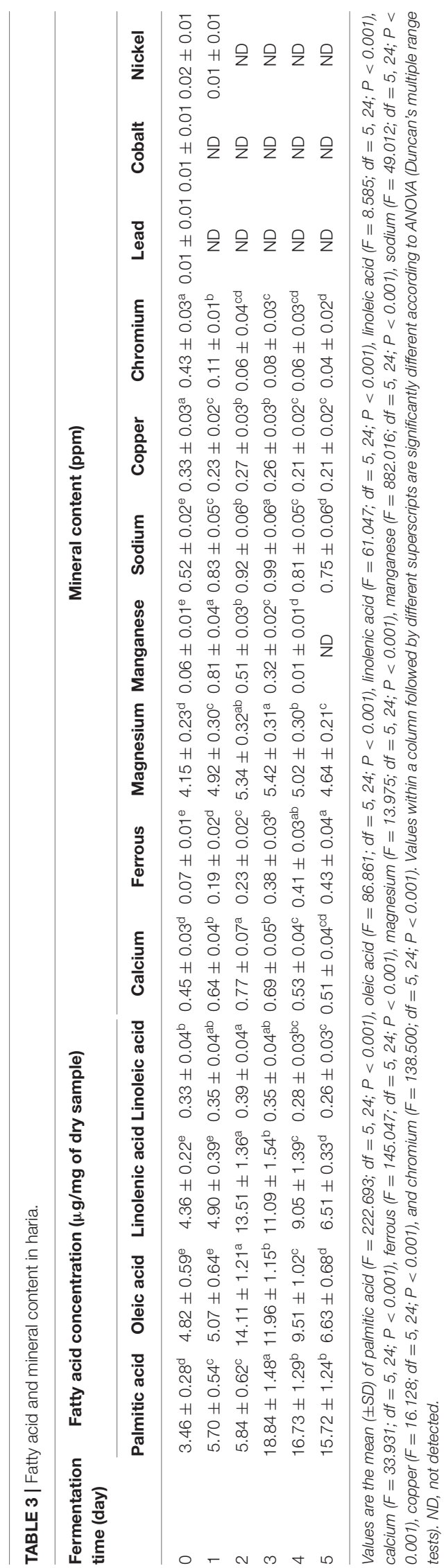




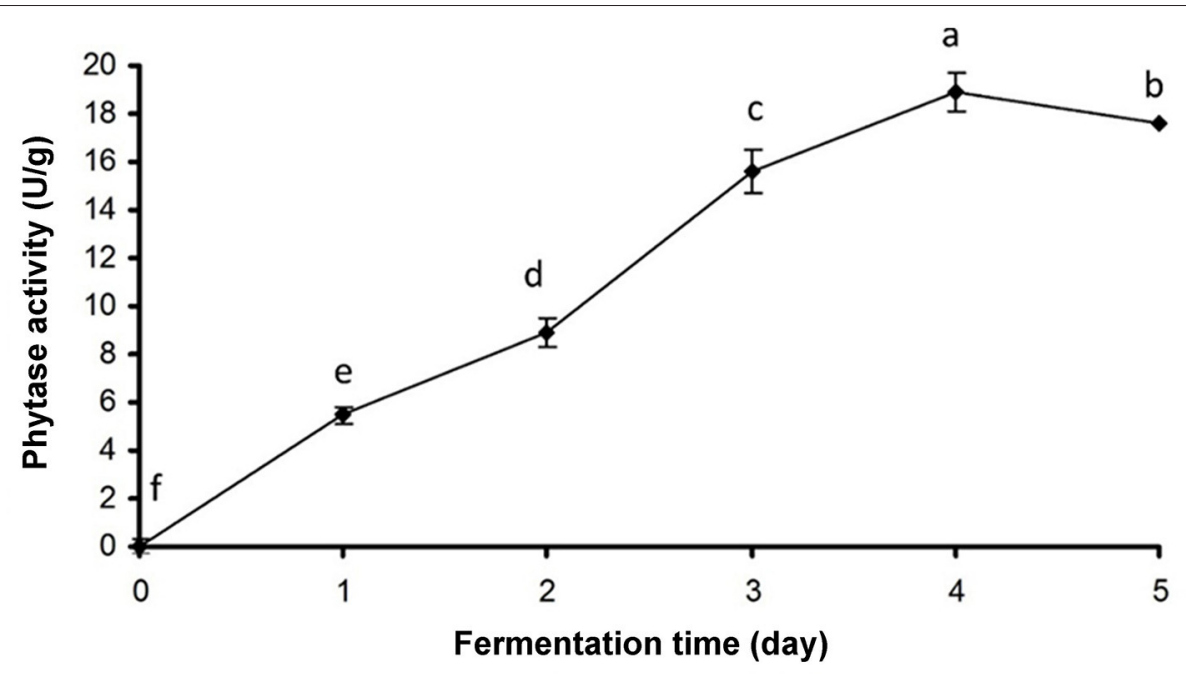

FIGURE 3 | Phytase activity of haria. Bars represent SD values of replicates. Values are the mean $( \pm S D)$ of phytase activity $(F=851.341 ;$ df $=5,24 ; P<0.001)$ Different letters on the bars are significantly different $(P<0.001)$ in Duncan's multiple range test.

$\mathrm{LAB}$ are considered as health beneficial probiotic organism and are emerging for present day's biotherapeutics. The multistrain and multispecies lactic acid bacterial composition makes this beverage more health beneficial. Kim et al. (2010) identified L. plantarum, Leuconostoc pseudomesenteroides, L. paracasei, L. harhibinensis, and L. parabuchneri in a Korean rice wine "takju" analyzed by using PCR-DGGE technique. Osimani et al. (2015) found different types of LAB by using PCRDGGE analysis, such as Weissella confusa, Weissella oryzae, Leuconostoc citreum, Lactococcus lactis, Pediococcus parvulus, Pediococcus ethanolidurans, and L. casei in boza, in a cerealbased fermented beverage of Bulgaria. Bhaati Jaanr, a similar type of rice beverage in India, also contain L. bifermentans (Tamang and Thapa, 2006). Marsh et al. (2014) stated that the room temperature at initial stage of rice fermentation favors the growth of mesophilic bacteria such as Lactococcus and Leuconostoc, whereas in the later stage, when the temperature of the fermented material increased due to microbial interaction/metabolism, thermophilic bacteria such as Lactobacillus and Streptococcus are augmented (Marsh et al., 2014). This may be one of the reasons for phasic occurrence of diverse groups of LAB in the haria fermentation.

The decrease in firmness of haria was observed as the fermentation proceeded (Figure 2). The gel firmness might be caused by retrogradation of starch gels, which could be associated with the syneresis of water and crystallization of amylopectin leading to harder gels (Miles et al., 1985). Similarly, the value of the consistency and cohesiveness were decreased during fermentation; hence, it can be stated that the starch gel became thinner either the action of amylolytic enzymes or the granules took up the moisture during fermentation (Hor et al., 2021). It has already reported that haria contains amylolytic enzymes such as $\alpha$-amylase and gluco-amylase (Ghosh et al., 2015a). The participating microbes secreted sufficient amylase, which can degrade the starch granule and thus reduce the consistency and cohesiveness of the fermented material.

The extent release of starch from rice granule depends on acidity of the medium, composition (amylose/amylopectin ratio), structure of the granule, degree of gelatinization, and swelling power. Lower $\mathrm{pH}$ and enzyme (amylase) produced by the microorganisms during fermentation (Ghosh et al., 2014, 2015a) facilitated the release of starch fraction from rice granule, and hence, viscosity was gradually increased up to the third day (Figure 2). However, the large starch granule degradation and sugar consumption rate (by alcohol producing yeast and other microorganisms) was higher than the amylose release rate; therefore, viscosity of the material was decreased gradually after the third day.

Most LAB are able to metabolize glucose or starch by homolactic or heterolactic fermentation to produce lactic acid, which further creates the unfavorable condition for the growth of pathogenic organisms ( $\mathrm{Lv}$ et al., 2012). In our earlier study, it was observed that the $\mathrm{pH}$ of the fermented material was gradually decreased, and at the end of the fermentation (fifth day), the $\mathrm{pH}$ was 3.55 (Ghosh et al., 2014). The decrease in $\mathrm{pH}$ during fermentation is likely due to utilization of free sugars (Efiuvwevwere and Akona, 1995; Mugochi et al., 2001) and accumulation of organic acids (e.g., lactic acid and other) during the course of microbial growth (Nyanga et al., 2008). It was observed that the concentration of lactic acid and acetic acid increased concurrently and reached the highest level on the fifth day (Table 2). Puerari et al. (2015) found $1.4 \mathrm{~g} / \mathrm{L}$ of lactic acid in chicha, a rice-based fermented beverage produced by Umutina Brazilian Amerindians. Lactic acid has several health beneficial effects like immune stimulatory, cholesterol lowering, inducer for endocrine secretion, stress remover, and brain stimulating and show protective roles for intestinal mucosa, flora, and overall intestinal functions (Ghosh et al., 2014). 
TABLE 4 | GC-MS analysis of sugar derivatives produced during the course of Haria fermentation.

\begin{tabular}{|c|c|c|c|}
\hline Retention time (min) & Compound name & Formula & Expected MW (kDa) \\
\hline 8.44 & Dichloroacetic acid heptadecyl ester & $\mathrm{C}_{19} \mathrm{H}_{36} \mathrm{O}_{2} \mathrm{Cl}_{2}$ & 366 \\
\hline 8.854 & Bicyclo(3.3.1)non-2-ene & $\mathrm{C}_{9} \mathrm{H}_{14}$ & 122 \\
\hline 11.14 & Ethanone,1-(2,4,6-trihydrophenyl) & $\mathrm{C}_{8} \mathrm{H}_{8} \mathrm{O}_{4}$ & 168 \\
\hline 13.74 & Chloroacetic acid, dodecyl ester & $\mathrm{C}_{14} \mathrm{H}_{27} \mathrm{O}_{2} \mathrm{Cl}$ & 262 \\
\hline 14.46 & 2H-indene3,3a,4,5,6,7-hexahydro & $\mathrm{C}_{9} \mathrm{H}_{14}$ & 122 \\
\hline 16.16 & Mucoinisitol, hexaacetate & $\mathrm{C}_{18} \mathrm{H}_{24} \mathrm{O}_{12}$ & 432 \\
\hline 19.68 & Chloroacetic acid, tetradecyl ester & $\mathrm{C}_{16} \mathrm{H}_{31} \mathrm{O}_{2} \mathrm{Cl}$ & 290 \\
\hline 19.817 & 1-Acetyl-3-(6-methyl-3-pyridyl)pyrazoline & $\mathrm{C}_{11} \mathrm{H}_{130} \mathrm{~N}_{3}$ & 203 \\
\hline 22.08 & Epi-inositol, hexaacetate & $\mathrm{C}_{18} \mathrm{H}_{24} \mathrm{O}_{12}$ & 432 \\
\hline 27.01 & N-(3-methyl-4-propionylphenyl)acetamide & $\mathrm{C}_{12} \mathrm{H}_{15} \mathrm{O}_{2} \mathrm{~N}$ & 205 \\
\hline 28.21 & 1H-indene,2,3,4,5,6,7-hexahydro & $\mathrm{C}_{9} \mathrm{H}_{14}$ & 122 \\
\hline
\end{tabular}

The best fitted compounds were selected according to Perkin-elmer inbuilt NIST mass spectral library and analyses by GC-MS TurboMass software detected in the GC-MS.

Rice contains different types of vitamins, but these vitamins are easily destroyed during processing such as milling, cooking, etc. During fermentation of cereals, the participating microbes, mainly LAB, are able to produce vitamins specifically the B vitamins (riboflavin, folic acid, etc.) (Capozzi et al., 2012). Haria contains different types of hydrosoluble vitamins (folic acid, thiamine, pyridoxine, and ascorbic acid), and their amounts were comparatively higher than the unfermented rice (Table 2). Therefore, it can be argued that microbial interplay might fortify the rice with adequate quantity of vitamins, which are very essential for human health. It was already proved that the amount of folic acid, niacin, riboflavin, and vitamins B12 and B6 were increased when fermentation is led by LAB (Shahani and Chandan, 1979; Alm, 1982). On the other hand, riboflavin content was gradually decreased during fermentation; probably, the participating microbes could not synthesize riboflavin or the microbes utilized for their growth. Boza contained thiamine, riboflavin, pyridoxine, and nicotinamid (Arici and Daglioglu, 2002). Basappa (2002) reported about the production of vitamin cyanocobalamin during finger millet fermentation by the participating microbes. In addition, the presence of different fatty acids in haria (Table 3) might enrich it with different health beneficial effects. Palmitic acid (C16:0) could alter the central nervous system for insulin secretion and suppress the body's natural appetite-suppressing signals from leptin and insulin in a rat model (Benoit et al., 2009). Moreover, linolenic acid (13.51 $\mu \mathrm{g} / \mathrm{mg})$ and linoleic acid $(0.39 \mu \mathrm{g} / \mathrm{mg}$ ) (Table 3) had antiobesitic, anticarcinogenic, antiatherogenic, antidiabetagenic, immunomodulatory, apoptotic, and osteosynthetic effects (Benjamin and Spener, 2009). Clearly, the presence of vitamins and fatty acids enriched the beverage.

Phytate is a natural antinutrient mostly present in cereals (Lopez et al., 2000). Its negatively charged phosphate groups form very stable complex with minerals (particularly divalent cations) causing unavailability of ions for intestinal absorption (Lopez et al., 2002). Phytase (myo-inositol hexakisphosphate phosphohydrolase, EC 3.1.3.8) degrades phytic acid (dephytinization) into myo-inositol and inorganic phosphate and helps in the unfasten of the minerals (De Angelis et al., 2003). It is now considered as an industrially important value-aided enzyme for quality improvement of phytate-rich feed and fodders (Singh and Satyanarayana, 2008). De Angelis et al. (2003) reported about the production of phytase by Lactobacillus sp. Due to dephytinization by the phytase enzyme, haria contain high amount of free minerals such as $\mathrm{Ca}^{++}, \mathrm{Fe}^{++}, \mathrm{Mg}^{++}$, $\mathrm{Mn}^{++}$, and $\mathrm{Na}^{+}$(Table 3) probably due to the production of phytase enzyme (Figure 3). These minerals may contribute significant impact on mineral balance as well as physiological homeostatis of consumers. Chakrabarty et al. (2014) observed that the mineral contents were increased during judima (a glutinous fermented rice in Northeast India) fermentation. The level of $\mathrm{Ca}, \mathrm{Fe}, \mathrm{Na}, \mathrm{K}$, and $\mathrm{P}$ were also improved in Bhati jaanr (Tamang and Thapa, 2006). Besides, $\mathrm{Cu}$ and $\mathrm{Cr}$ contents were gradually decreased during the fermentation of haria. Huang et al. (2015) demonstrated that foodborne Lactobacillus paracase has chromate reduction ability. Moreover, specific probiotic bacteria have the capacity to remove different types of heavy metals by adsorbing on their surface (Halttunen et al., 2008).

The aroma and taste of alcoholic beverages are critical to their acceptance by consumers, and the primary determinants of aroma and taste are volatile compounds (Arellano et al., 2012). Eleven types of volatile compounds were detected in haria by GC-MS (Table 4). Among these volatile compounds, three esters, namely, dichloroacetic acid heptadecyl ester, chloroacetic acid dodecyl ester, and chloroacetic acid tetradecyl ester, were detected. These esters give a unique flavor and aroma to haria. Production of these esters are generally controlled by the enzyme, acylcoenzyme A, which may be produced by the participating microbes, mainly yeast (Miller et al., 2007; Arellano et al., 2012). Chen and $\mathrm{Xu}$ (2010) also found different types of esters in Chinese wine, which was mainly fermented by yeast. Inositol (myo- and epi-inositol) has been found to be therapeutically effective in depression, panic disorder, and obsessive-compulsive disorder in double-blind controlled trials (Bersudsky et al., 1999).

\section{CONCLUSION}

The present study for the first time demonstrated that a group of lactic acid bacteria interplayed during the 
fermentation of haria, and these bacteria originated from herbal residues. The application of PCR-DGGE-based metagenomic approach has been facilitated to explore the occurrence and dynamics of specific group of LAB at each stage of fermentation. The synergistic action of lactic acid bacterial consortia and other microorganisms (Bacillus sp. and yeast) fortified the rice by decreasing antinutrient phytic acid and improving the bioavailability of minerals, lactic acid, and acetic acid. All these credible scientific evidence supported its traditional use and putative health beneficial attributes. Proper scientific intervention by standardizing the process parameters and the adaptation of newer technologies will be helpful for the exploitation this beverage as functional and healthy drink for the world community.

\section{REFERENCES}

Alm, L. (1982). Effect of fermentation on B-vitamin content of milk in Sweden. J. Dairy Sci. 65, 353-359. doi: 10.3168/jds.S0022-0302(82)82199-1

Arellano, M., Gschaedler, A., and Alcazar, M. (2012). Major Volatile Compounds Analysis Produced From Mezcal Fermentation Using Gas Chromatography Equipped Headspace (GC-HS). Rijeka: InTech, 73-88. doi: 10.5772/33415

Arici, M., and Daglioglu, O. (2002). Boza: a lactic acid fermented cereal beverage as a traditional Turkish food. Food Rev. Int. 18, 39-48. doi: 10.1081/FRI-120003416

Basappa, S. (2002). Investigations on Chhang from finger millet (Eleucine Coracana Gaertn.) and its commercial prospects. Indian Food Indus. 21, 46-51.

ben Omar, N., and Ampe, F. (2000). Microbial community dynamics during production of the Mexican fermented maize dough pozol. Appl. Environ. Microbiol. 66, 3664-3673. doi: 10.1128/AEM.66.9.3664-3673.2000

Benjamin, S., and Spener, F. (2009). Conjugated linoleic acids as functional food: an insight into their health benefits. Nutr. Metab. 6:36. doi: 10.1186/1743-7075-6-36

Benoit, S. C., Kemp, C. J., Elias, C. F., Abplanalp, W., Herman, J. P., Migrenne, S., et al. (2009). Palmitic acid mediates hypothalamic insulin resistance by altering PKC- $\theta$ subcellular localization in rodents. J. Clin. Invest. 119:2577. doi: 10.1172/JCI36714

Bersudsky, Y., Einat, H., Stahl, Z., and Belmaker, R. H. (1999). Epi-inositol and inositol depletion: two new treatment approaches in affective disorder. Curr. Psychiatry Rep. 1, 141-147. doi: 10.1007/s11920-999-0023-z

Blandino, A., Al-Aseeri, M. E., Pandiella, S. S., Cantero, D., and Webb, C. (2003). Cereal-based fermented foods and beverages. Food Res. Int. 36, 527-543. doi: 10.1016/S0963-9969(03)00009-7

Capozzi, V., Russo, P., Dueñas, M. T., López, P., and Spano, G. (2012). Lactic acid bacteria producing B-group vitamins: a great potential for functional cereals products. Appl. Microbiol. Biotechnol. 96, 1383-1394. doi: 10.1007/s00253-012-4440-2

Chakrabarty, J., Sharma, G., and Tamang, J. P. (2014). Traditional technology and product characterization of some lesser-known ethnic fermented foods and beverages of North Cachar Hills District of Assam. Indian J. Traditional Knowl. $13,706-715$.

Chen, S., and $\mathrm{Xu}, \mathrm{Y}$. (2010). The influence of yeast strains on the volatile flavour compounds of Chinese rice wine. J. Inst. Brew. 116, 190-196. doi: 10.1002/j.2050-0416.2010.tb00417.x

Coda, R., Rizzello, C. G., Trani, A., and Gobbetti, M. (2011). Manufacture and characterization of functional emmer beverages fermented by selected lactic acid bacteria. Food Microbiol. 28, 526-536. doi: 10.1016/j.fm.2010.11.001

Daley, C. A., Abbott, A., Doyle, P. S., Nader, G. A., and Larson, S. (2010). A review of fatty acid profiles and antioxidant content in grass-fed and grain-fed beef. Nutr. J. 9:10. doi: 10.1186/1475-2891-9-10

\section{DATA AVAILABILITY STATEMENT}

The datasets presented in this study can be found in online repositories. The names of the repository/repositories and accession number(s) can be found at: https://www. ncbi.nlm.nih.gov/genbank/, KU248768 https:/www.ncbi.nlm. nih.gov/genbank/, KU248769.

\section{AUTHOR CONTRIBUTIONS}

KG and KM conceived and designed the experiments. KG and AA performed the experiments. KG wrote the paper. $\mathrm{KM}$ and $\mathrm{SH}$ critically revised the manuscript. $\mathrm{KG}, \mathrm{AA}, \mathrm{SH}$, and $\mathrm{KM}$ approved the manuscript. All authors contributed to the article and approved the submitted version.

Das, A., Raychaudhuri, U., and Chakraborty, R. (2012). Cereal based functional food of Indian subcontinent: a review. J. Food Sci. Technol. 49, 665-672. doi: 10.1007/s13197-011-0474-1

De Angelis, M., Gallo, G., Corbo, M. R., McSweeney, P. L., Faccia, M., Giovine, M., et al. (2003). Phytase activity in sourdough lactic acid bacteria: purification and characterization of a phytase from Lactobacillus sanfranciscensis CB1. Int. J. Food Microbiol. 87, 259-270. doi: 10.1016/S0168-1605(03)00072-2

Efiuvwevwere, B., and Akona, O. (1995). The microbiology of 'kunun-zaki', a cereal beverage from Northern Nigeria, during the fermentation (production) process. World J. Microbiol. Biotechnol. 11, 491-493. doi: 10.1007/BF00286358

Ghosh, K., Mondal, S. P., and Mondal, K. C. (2020). "Ethnic fermented foods and beverages of West Bengal and Odisha," in Ethnic Fermented Foods and Beverages of India: Science History and Culture, ed. J. P. Tamang (Singapore: Springer Nature), 647-685.

Ghosh, K., Ray, M., Adak, A., Dey, P., Halder, S. K., Das, A., et al. (2015a). Microbial, saccharifying and antioxidant properties of an Indian rice based fermented beverage. Food Chem. 168, 196-202. doi: 10.1016/j.foodchem.2014.07.042

Ghosh, K., Ray, M., Adak, A., Halder, S. K., Das, A., Jana, A., et al. (2015b). Role of probiotic Lactobacillus fermentum KKL1 in the preparation of a rice based fermented beverage. Bioresour. Technol. 188, 161-168. doi: 10.1016/j.biortech.2015.01.130

Ghosh, K., Maity, C., Adak, A., Halder, S. K., Jana, A., Das, A., et al. (2014). Ethnic preparation of haria, a rice-based fermented beverage, in the province of lateritic West Bengal, India. Ethnobotany Res. Appl. 12, 39-49.

Halttunen, T., Collado, M., El-Nezami, H., Meriluoto, J., and Salminen, S. (2008) Combining strains of lactic acid bacteria may reduce their toxin and heavy metal removal efficiency from aqueous solution. Lett. Appl. Microbiol. 46, 160-165. doi: 10.1111/j.1472-765X.2007.02276.x

Hor, P. K., Ghosh, K., Halder, S. K., Soren, J. P., Goswami, D., Bera, D., et al. (2021). Evaluation of nutrient profile, biochemical composition and anti-gastric ulcer potentialities of khambir, a leavened flat bread. Food Chem. 345:128824. doi: 10.1016/j.foodchem.2020.128824

Huang, G., Wang, W., and Liu, G. (2015). Simultaneous chromate reduction and azo dye decolourization by Lactobacillus paracase CL1107 isolated from deep sea sediment. J. Environ. Manage. 157, 297-302. doi: 10.1016/j.jenvman.2015.04.031

Kim, S. Y., Yoo, K. S., Kim, J., Kim, J. S., Jung, J., Jin, Q., et al. (2010). Diversity analysis of lactic acid bacteria in Korean rice wines by cultureindependent method using PCR-denaturing gradient gel electrophoresis. Food Sci. Biotechnol. 19, 749-755. doi: 10.1007/s10068-010-0105-z

Lopez, H. W., Leenhardt, F., Coudray, C., and Remesy, C. (2002). Minerals and phytic acid interactions: is it a real problem for human nutrition? Int. J. Food Sci. Technol. 37, 727-739. doi: 10.1046/j.1365-2621.2002. 00618.x 
Lopez, H. W., Ouvry, A., Bervas, E., Guy, C., Messager, A., Demigne, C., et al. (2000). Strains of lactic acid bacteria isolated from sour doughs degrade phytic acid and improve calcium and magnesium solubility from whole wheat flour. J. Agric. Food Chem. 48, 2281-2285. doi: 10.1021/jf0 $00061 \mathrm{~g}$

Lv, X. C., Weng, X., Zhang, W., Rao, P. F., and Ni, L. (2012). Microbial diversity of traditional fermentation starters for Hong $\mathrm{Qu}$ glutinous rice wine as determined by PCR-mediated DGGE. Food Control 28, 426-434. doi: 10.1016/j.foodcont.2012.05.025

Marsh, A. J., Hill, C., Ross, R. P., and Cotter, P. D. (2014). Fermented beverages with health-promoting potential: past and future perspectives. Trends Food Sci. Technol. 38, 113-124. doi: 10.1016/j.tifs.2014. 05.002

Miles, M. J., Morris, V. J., Orford, P. D., and Ring, S. G. (1985). The roles of amylose and amylopectin in the gelation and retrogradation of starch. Carbohydr. Res. 135, 271-281. doi: 10.1016/S0008-6215(00)90778-X

Miller, A. C., Wolff, S. R., Bisson, L. F., and Ebeler, S. E. (2007). Yeast strain and nitrogen supplementation: dynamics of volatile ester production in Chardonnay juice fermentations. Am. J. Enol. Vitic. 58, 470-483.

Mugochi, T., Mutukumira, T., and Zvauya, R. (2001). Comparison of sensory characteristics of traditional Zimbabwean non-alcoholic cereal beverages, masvusvu and mangisi with mahewu, a commercial cereal product. Ecol. Food Nutr. 40, 299-309. doi: 10.1080/03670244.2001.9991655

Nout, M. J. R. (2009). Rich nutrition from the poorest - Cereal fermentations in Africa and Asia. Food Microbiol. 26, 685-692. doi: 10.1016/j.fm.2009.07.002

Nyanga, L. K., Nout, M. J. R., Gadaga, T. H., Boekhout, T., and Zwietering, M. H. (2008). Traditional processing of masau fruits (Ziziphus Mauritiana) in Zimbabwe. Ecol. Food Nutr. 47, 95-107. doi: 10.1080/03670240701702321

Osimani, A., Garofalo, C., Aquilanti, L., Milanovic, V., and Clementi, F. (2015). Unpasteurised commercial boza as a source of microbial diversity. Int. J. Food Microbiol. 194, 62-70. doi: 10.1016/j.ijfoodmicro.2014.11.011

Puerari, C., Magalhães-Guedes, K. T., and Schwan, R. F. (2015). Physicochemical and microbiological characterization of chicha, a rice-based fermented beverage produced by Umutina Brazilian Amerindians. Food Microbiol. 46, 210-217. doi: 10.1016/j.fm.2014.08.009
Ray, M., Ghosh, K., Singh, S., and Mondal, K. C. (2016). Folk to functional: an explorative overview of rice-based fermented foods and beverages in India. $J$. Ethnic Foods. 3, 5-18. doi: 10.1016/j.jef.2016.02.002

Ritchie, L. E., Burke, K. F., Garcia-Mazcorro, J. F., Steiner, J. M., and Suchodolski, J. S. (2010). Characterization of fecal microbiota in cats using universal $16 \mathrm{~S}$ rRNA gene and group-specific primers for Lactobacillus and Bifidobacterium spp. Vet. Microbiol. 144, 140-146. doi: 10.1016/j.vetmic.2009.12.045

Shahani, K. M., and Chandan, R. C. (1979). Nutritional and healthful aspects of cultured and culture-containing dairy foods. J. Dairy Sci. 62, 1685-1694. doi: 10.3168/jds.S0022-0302(79)83481-5

Shimizu, M. (1992). Purification and characterization of phytase from Bacillus subtilis (natto) N-77. Biosci. Biotechnol. Biochem. 56, 1266-1269. doi: 10.1271/bbb.56.1266

Singh, B., and Satyanarayana, T. (2008). Phytase production by Sporotrichum thermophile in a cost-effective cane molasses medium in submerged fermentation and its application in bread. J. Appl. Microbiol. 105, 1858-1865. doi: 10.1111/j.1365-2672.2008.03929.x

Steinkraus, K. H. (1998). "Bio-enrichment: production of vitamins in fermented foods," in Microbiology of Fermented Foods, ed. J. B. Wood (London: Blackie Academic and Professional), 603-619.

Tamang, J. P., and Thapa, S. (2006). Fermentation dynamics during production of bhaati jaanr, a traditional fermented rice beverage of the Eastern Himalayas. Food Biotechnol. 20, 251-261. doi: 10.1080/08905430600904476

Conflict of Interest: The authors declare that the research was conducted in the absence of any commercial or financial relationships that could be construed as a potential conflict of interest.

Copyright (c) 2021 Ghosh, Adak, Halder and Mondal. This is an open-access article distributed under the terms of the Creative Commons Attribution License (CC BY). The use, distribution or reproduction in other forums is permitted, provided the original author(s) and the copyright owner(s) are credited and that the original publication in this journal is cited, in accordance with accepted academic practice. No use, distribution or reproduction is permitted which does not comply with these terms. 